\title{
DEMOCRATIC TRANSITION IN MALAYSIA: PREREQUISITES AND OBSTACLES
}

\author{
Syed Farid Alatas*
}

\begin{abstract}
This paper discusses three factors accounting for the transition to democracy, namely the absence of mass or armed resistance to democracy, the internal strength of the state, and the cohesion of the political elite. In the case of Malaysia, the structural conditions that emerged in the late colonial period, that is the absence of mass resistance movements, allowed for the rise of a relatively democratic postcolonial state. Conditions had been relatively conducive to the development of democratic political culture. However, recent years have seen the development and exertion of a more authoritarian trend among the political and religious elite that has accompanied a process of "Islamisation" of governance. These developments resonate with a more feudal, hierarchical and authoritarian culture that can be traced to the pre-colonial past and which has an affinity with a more authoritarian interpretation of Islam so typical of the contemporary state religious establishment. The future of democracy in Malaysia depends on the ability of democratic tendencies within the state as well as civil society to work against these authoritarian forces. This future would require drawing upon the more egalitarian and humanist tradition of precolonial Islam and the modernist movement of the colonial Malay world.
\end{abstract}

\section{Democracy in Malaysia ${ }^{1}$}

Malaysia has maintained a relatively democratic regime since independence. Such characterisation is likely to raise objection, with some referring to the state as authoritarian, yet others depicting it as neither democratic nor authoritarian. Therefore, it is necessary to justify the designation of Malaysia as a democratic state.

While it can be conceded that the Malaysian state does not "live up" to the standards of Western liberal democracies, nor aspires to, it is a system in which democratic procedures and institutions distinguish it qualitatively from many other states customarily understood to be authoritarian. In his discussion on the nature of democracy, Raymond Aron presents all regimes as oligarchic, whether democratic or authoritarian. The essence of politics is such that decisions are taken for and not by the community. Popular sovereignty should not be taken to mean that 
the people are directly involved in decision-making. ${ }^{2}$ Yet if every regime masks an oligarchy, how can democracies be distinguished from authoritarian regimes? Important distinctions lie in the way power is wielded, the rules according to which the dominant minority governs, the extent to which the ruling minority is open, and how it is selected. The political system is democratic to the extent that the ruling minorities of the regime are open for entry by way of democratic procedures. Along these lines of argument, it is fair to say that Malaysia, relative to liberal democracies, may have been corrupted by too much oligarchy, yet this does not render it an authoritarian state. Instead, it is the relatively free elections that give power to representatives of privileged minorities.

While it may be true that democratic procedures would only be adhered to as long as the ruling elite maintains its positions of power and continues to advance its ideal and material interests, the conditions under this must be explained.

After attaining independence in 1957, general elections have been held regularly in Malaysia since August 1959. Subsequently, elections were held in 1964, 1969, 1974, 1978, 1982, 1986, 1990, 1995, 1999, 2004, 2008 and 2013. The post-independence period has seen six consecutive changes of heads of government and 12 general elections. ${ }^{3}$ Throughout this period civilian authority in the state has been the rule. The democratic nature of the state is certainly qualified, yet it is more than merely formal. Political parties from both the government and opposition exist at the national as well as regional levels. Apart from an almost two-year period of "suspended democracy" following racial riots after the 1969 elections, parliamentary democracy has functioned continuously. Whatever the causes of the suspension of democracy were, they did not operate sufficiently long enough, nor were they severe enough, to produce a non-democratic state. These features distinguish Malaysia qualitatively from authoritarian states.

\section{The Conditions for Democracy}

It should be evident that for most of post-colonial history, the Malaysian state has some features which set it apart from Third World authoritarian regimes, which tend to be totalitarian, military-dominated, one-party systems, or bureaucratic authoritarian. The regularity of general elections, universal suffrage, the legal existence of opposition parties, and the degree of political contestation, co-exist with a powerful state which derives legitimacy from the functioning of democratic institutions and continues to play a dominant role in structuring politics and social life ${ }^{4}$ As noted by Girling, democratic elections do have substance in Malaysia because "alternative choices to the ruling party alliance still exist." 
semi- or statist nature of Malaysia's democracy should not therefore give the impression that democracy here is merely a facade.

The conditions for democracy in Malaysia are the following:

i. The lack of armed resistance against the state.

Democracy was implanted in Malaysia from without. One of the conditions under which it can survive is an absence of armed resistance to the democratic programme and state. The Malaysian post-colonial state had never been up against mass or armed movements. There was no war of independence, and the lower classes were neither participants nor sources of pressure in the negotiations between the British and the Malayan elite for self-rule. The only militant element in Malayan labour was associated with the Communist Party of Malaya (CPM). The emerging Malaysian government, however, refused to accept the legal existence of the CPM in an independent Malaysia. Meanwhile, during the period of the emergency imposed by the British for twelve years from 1948, the guerrilla and terrorist activities of the CPM failed to gain the support of the masses. ${ }^{6}$

In Malaya, credit for the success of the government counter-insurgency policy against the CPM must go to the British, as the more significant part of the emergency period (lasting from 1948 to 1960) occurred during colonial rule. In fact, in 1956, a year before independence, Tunku Abdul Rahman, the nation's first Prime Minister, declared that the government would only build up a small army so as not to sap the resources of the country. ${ }^{7}$ This piece of history indicates that the emerging government of independent Malaya did not see the CPM as a substantial threat to the security of the country; there were no plans to build up the armed forces and the police on a scale necessary to fight a communist insurgency. It seems that the government of post-colonial Malaya "did not bestir itself unduly over the military threat posed by the CPM...." The left was heavily suppressed, but most of this suppression took place during the British period. By the time of formal independence, there was not much left of an anti-government movement to suppress.

\section{ii. Internal Strength of the State}

The internal strength of the state can be seen in terms of both the resources it can mobilise in situations where its power is challenged ${ }^{9}$ and in the support it receives from the dominant classes, whether industrial, merchant capital, or landed. An internally strong state need not suspend democracy to withstand opposition. Moore referred to the strong bourgeois impulse as a requirement for democracy. The underlying general principle is that strong class backing is needed for the 
democratic state. In the case of modern capitalist states, this backing comes in the form of taxation, the stock exchange and commercial credit. ${ }^{10}$

In the case of Malaysia, internal state strength, and the support that the state receives from the dominant classes in particular, is linked to the ethnic dimension, simply because of the predominance of domestic Chinese capital. In the early years after independence, the Chinese fraction of capital was dominant, as Malay capital was significantly undeveloped. ${ }^{11}$ Later, however, the launch of the New Economic Policy (NEP) in the 1970s brought a new set of rules, regulations and constraints on Chinese capital, which allowed for the emergence of politically-connected Malay private capital by way of "Ali-Baba" arrangements, appointments to company directorships, and the procurement of government contracts, not to mention the increasing role of foreign capital since the 1970s. ${ }^{12}$ Also, Malay bureaucrat capitalists, that is those who hold or once held bureaucratic posts and use such posts for initial capital accumulation, ${ }^{13}$ made their indelible mark on the economic landscape.

Although Chinese community support for the MCA (Malayan Chinese Association) has been in decline since 1959, with the implementation of the NEP the MCA has lost significant ground to other Chinese-based opposition parties over the last three decades. ${ }^{14}$ The NEP has also resulted in the constriction of Chinese capital ${ }^{15,16}$ and, therefore, the ability of the MCA to bring in votes, which is linked to its access to capital. Nevertheless, the MCP is still significant because of the role it plays in "reinforcing Chinese ethnic identity and giving it concrete expression" in economic activity. ${ }^{17}$ Despite a history of Malay-Chinese antagonism, including the riots of May 1969, Malay sentiments towards the Chinese have never been such that Chinese capital could not aspire to ruling class status. This has provided for some degree of democratic stability that includes the provision of funds to UMNO (United Malays National Organisation) politicians from Chinese capitalists, which was as accurate of the 1950s as it is of today. ${ }^{18}$ The alliance of state and capital, as seen in the form of the Barisan Nasional (BN) today, is still vital despite the relative loss of clout of Chinese capital.

Thus, despite the change in the ethnic composition of capital, and whatever the direction and magnitude of such change in state-capital business relationships since independence, the state has continuously had a solid financial basis and access to funds.

\section{iii. Elite Cohesion}

The question of why and how Malaysia's style of democracy emerged and stabilised can be further addressed by recourse to an elite perspective on democratic stability. 
From 1957 to 1969, UMNO, MCA and MIC (Malayan Indian Congress) achieved a consensus on vital questions concerning the special position of the Malays, the status of Malay as the official language of the country, and citizenship for non-Malays. ${ }^{19}$ However, the alliance between Malay and Chinese elites broke down temporarily when the Central Working Committee of the MCA said that the party would not join the new Alliance cabinet as Chinese voters "rejected the MCA to represent them in the Government, if the result of the general elections reflect their wishes. ${ }^{20}$ Nevertheless, when the new cabinet was formed on 20 May 1969, the MCA continued to be part of it, providing three "Ministers with Special Functions." ${ }^{21}$ Although there was still talk of withdrawing from the cabinet when the situation returned to normal, the Chinese Chamber of Commerce was able to persuade the MCA to reconsider its participation in the cabinet. ${ }^{22}$ The potential for protracted elite factionalism between the MCA and UMNO was manifest in the views of some UMNO politicians who were against a continued alliance with the MCA. However, what finally took place was a power struggle within UMNO itself. When Tun Tan Siew Sin announced that the MCA would not be in the cabinet, he was openly supported by UMNO "ultra" politicians such as Mahathir Mohamad, Syed Ja'afar Albar and Syed Nasir Ismail, who wished for UMNO to go it alone in the cabinet. ${ }^{23}$ The elite factionalism therefore was within the Malay leadership and not between Malays and Chinese as such. Tunku Abdul Rahman even told the Malay weekly, Utusan Zaman, that Malay extremists within UMNO wanted to topple him. ${ }^{24}$

Nevertheless, the MCA eventually participated in the cabinet, and the problem of leadership within UMNO was resolved when Tun Razak replaced the Tunku as Prime Minister in September 1970. What is interesting is that the elite factionalism that surfaced during this period was intra-Malay rather than interethnic. The "ultra" Malay UMNO elite did not move to expel the MCA from the cabinet, but simply supported the MCA's earlier decision not to be in the cabinet. So the real conflict was within UMNO itself; the MCA issue was merely used to discredit rival elites.

It should also be noted that the period of relative elite cohesion in Malaysia during the formative period of the post-colonial state was in the context of an internally strong state and a non-politicised military. Although ethnically divided, the state was politically homogenous and united in the interests of the state and capital. There was no serious threat to the status quo after 1969 that could have ended parliamentary democracy. 


\section{The State of Democracy Today}

In terms of all three prerequisites of democracy, the state seems to be faring well. Armed resistance in the form of separatist movements and terrorism, of the sort that have threatened the integrity of other states, such as Indonesia, often providing a justification for authoritarianism, remain absent in Malaysia. To the extent that there is no exodus of Chinese capital from Malaysia, capital will continue to play the role of supporting the state as in the past. Regarding elite cohesion, at this point it would be difficult to speak of a factional split within the Malaysian political elite, even within UMNO itself. The Malaysian state is therefore still internally strong in the way that I have defined it.

At the same time, however, there has been a growing authoritarian trend in governance. The real test of our democratic state today lies in its attitude and tolerance towards criticism, opposition and dissent. We have seen a steady decline in such tolerance over the decades. In line with a feudal mentality, our government does not seem to see itself as a servant of the people, but rather as our masters.

How can we understand this beyond the political-economic context?

\section{Obstacles to Democratisation}

Although Malaysia has fulfilled the structural prerequisites for democracy in the way we have defined them, obstacles to the further development and consolidation of democracy remain. Here I discuss three obstacles, namely, the communal gap, the failure of capital to play a transformative role, and the persistence of feudal psychology.

\section{(a) The Communal Gap}

Malaysian politics has been divided by ethnicised politics and politicised ethnicity. This division is an inheritance of the country's colonial legacy. The British, wherever they went, sought to maintain ethnic and religious differences in the societies that they colonised in order to facilitate political control and hegemony. In consequence, while there has been a failure of alliances among both political parties and the citizenry along class lines, association has instead been primarily along ethnic and, increasingly, religious lines. The failure to associate along class lines is evident in the middle, urban working class, as well as in the rural classes. In fact, it is only the elite that associates along class lines. The Malay politicalbureaucratic elite and Chinese-dominated capital have forged a level of elite cohesion that is unassailable. While the elites have an interest in promoting and/ or being silent over an ethnically and religiously divisive discourse for public 
consumption, there is little consciousness of this divisiveness and its impact on the political and economic future of the country among the general population. The lack of such consciousness explains the inability of most Malaysians to think along class lines and is a severe obstacle towards the development of democracy.

(b) The Failure of Capital to Play a Transformative Role

What has been said above about the path Malaysia has taken towards democracy resonates with the so-called Moore thesis. According to Barrington Moore Jr in his seminal book, The Social Origins of Democracy and Dictatorship, the absence of a strong bourgeoisie will result in the failure of democracy to develop. The argument of the book is that differential strengths of the bourgeoisie create different paths for state formation. A stronger bourgeoisie makes for a democratic outcome, while a weaker bourgeoisie makes it more difficult to overcome the power of feudal structures. ${ }^{25}$

However, there are historical cases in which the bourgeoisie have failed to play such a transformative or revolutionary role. A classic case was discussed by Marx in his The Eighteenth Brumaire of Louis Bonaparte. ${ }^{26}$ Whereas the bourgeoisie played a revolutionary role in the French Revolution of 1789, its role in the revolution of 1848 was a farcical attempt to recreate the great revolution of fifty years earlier. ${ }^{27}$ Marx explains the rise of the authoritarian Louis Bonaparte in 1851 as a consequence of the bourgeoisie's fear of confronting the subjugated class, the proletariat, in the absence of a powerful state to mediate on their behalf. This is a case of the ruling class not wishing to exert itself forcefully but to give up its power. As Marx puts it:

the bourgeoisie confesses that its own interests dictate that it should be delivered from the danger of its own rule; that to restore tranquility in the country its bourgeois parliament must, first of all, be given its quietus; that to preserve its social power intact its political power must be broken; that the individual bourgeois can continue to exploit the other classes and to enjoy undisturbed property, family, religion, and order only on condition that their class be condemned along with the other classes to like political nullity; that in order to save its purse it must forfeit the crown, and the sword that is to safeguard it must at the same time be hung over its own head as a sword of Damocles. ${ }^{28}$

Indeed, this is what we may be seeing in the case of Malaysia. The presence of capital and its alliance with the state has not succeeded in transforming the political culture of the elite into a genuinely democratic one. In fact, it can be 
argued that the dominant political culture remains feudal in essence, a remnant from the pre-colonial past.

\section{(c) The Persistence of Feudalism in Malaysia ${ }^{29}$}

Shaharuddin Maaruf has an insightful analysis that provides us with a means of understanding today's growing authoritarian political culture. Shaharuddin defines tradition as cultural, as a value system which has been influential in moulding or shaping the world-view of a given people for a significant period in their history. These cultural or value systems represent the stable core which provides the basis for a society's response to contemporary and future challenges. ${ }^{30}$ Tradition can be a negative or positive factor in the development of a society. Speaking about the Malay world, Shaharuddin draws our attention to two opposing traditions in Malay society: the feudal and Islamic traditions. The conflict between these two is rooted in the past but still remains present in contemporary Malay society, even after the demise of the feudal polity. Malay feudal values have survived the feudal system.

An example is the tendency to spend lavishly on ceremonies and entertainment locally as well as abroad. It was noted by Syed Hussein Alatas in 1968 that "the mood and desire to spend on such objects have been continuous with the feudal past where the ruling power put a high premium on luxury, entertainment and recreation." "31 Years ago, the University of Malaya Academic Staff Association and the Students' Union used the term "psychological feudalism" to describe the university council due to its reluctance to seek student opinions on university matters. ${ }^{32}$ Alatas also referred to a certain practice of promotions being based on feudalism. He observed numerous cases of promotion in government departments, institutions of learning, companies, political parties, and public associations based not on an aspirant's capacity or talent, but on their willingness to resort to winning the favour of their superiors through sycophancy or impressive subservience..$^{33}$ These statements were made in the 1960s but are probably more relevant today than ever before.

Feudal values include: (1) a servile attitude towards authority and the acceptance of arbitrary notions of power; (2) the undermining of the positive aspects of individualism and, therefore, a lack of respect for the human personality; (3) lack of respect for the rule of law; (4) non-distinction between the public and personal domains of life; (5) emphasis on grandeur and an opulent lifestyle; (6) indifference to social justice; (7) acceptance of unfair privileges for those in positions of power; (8) obsession with power, authority and privileges for their own sake; (9) the undervaluing of rationalism and the philosophical spirit, and the encouragement of myths which serve the interests of those in power; 
and (10) emphasis on leisure and indulgence of the senses and the simultaneous undervaluing of work. ${ }^{34}$

These feudal values are not only at odds with the spirit and outlook of modernisation but also clash with the fundamental values of Islam. As opposed to such feudal values, Islamic tradition emphasises (1) a rational and egalitarian conception of authority; (2) limits to arbitrary power; (3) recognition of positive individualism and respect for the human personality; (4) the rule of law; (5) a humanistic conception of leadership; (6) ethical integrity and honesty in public office; (7) frugality; (8) social justice; (9) effort rather than unfair privileges; (10) the ideal of excellence for life on earth; (11) rationalism and the philosophical spirit; (12) disapproval of irrational belief and superstition; and (13) dignity of labour. ${ }^{35}$

Shaharuddin argues that both feudal and Islamic values exist in a conflicting relationship in Malay tradition. The question of progress in the modern era dramatically depends on the outcome of this conflict, that is, "on which value system gains the upper hand." ${ }^{36}$

\section{Conclusion: Theologising Democracy ${ }^{37}$}

As opposed to the alliance of capital and the religious bureaucracy to establish an authoritarian state with the trappings of religio-fascism, Malaysia needs to make democracy a part of its culture. One way to do this is by way of theologising democracy. The theologisation of democracy would stress egalitarian as opposed to feudal values and an appeal to social justice along the lines of need (class) rather than religion or ethnicity. A basis on which this can be done comes from the thought of Said Nursi (1877-1960), the late Ottoman theologian and thinker, who lived well into the Turkish republican era.

Turkey's Tanzimat period (1839-1876) was a period of Western-style reform which entailed, among other things, the separation of the religious from the worldly functions of government. Its goal was to halt the economic and political decline of the Ottoman Empire, as well as its subjection to Europe. In opposition to the Tanzimat, a group known as the Young Ottomans proposed constitutionalism, freedom and representative government while maintaining Islam as the foundation of the state. A leading proponent of the Constitutional Movement was Namık Kemal, who drafted Turkey's first constitution. Proclaimed on December 23, 1876, this new constitution was suspended by Sultan Abdulhamid II in 1878, pushing the struggle for constitutionalism underground. The writings of Kemal -probably banned by now- influenced many youths, including Said Nursi, who was sympathetic to the idea of uniting Islamic thought with ideas of constitutionalism and representative government. ${ }^{38}$ 
Nursi was active in the late Ottoman period as an active supporter of constitutional government, educational reforms, and the integrity of the Ottoman Empire during the reign of Abdulhamid's successor, Mehmed Resad. As part of these efforts, he travelled through the Arab domains of the Ottoman Empire and delivered the famous Damascus Sermon at the historic Umayyad Mosque in Damascus in the spring of 1911. At that time there was a need to speak of reform in the language of pan-Islam rather than Ottomanism or Turkish nationalism. This was because of the dissatisfaction many Arabs felt towards Ottoman rule, partly due to what they perceived to be the marginalisation of Arabic as the language of administration and the question of increasing Zionist settlement in Palestine. Nursi's task was to stress the need for commitment to the themes of progress, unity and constitutionalism for the sake of the integrity of the empire..$^{39}$

At Eskisehir Court, Nursi was asked, "What do you think of the Republic?" His reply was:

My biography, which you have in your possession, proves that I was a religious republican before any of you was born, with the exception perhaps of the Chairman of Eskisehir Court. A summary of it is this: like now, at that time I was living in seclusion in an uninhabited tomb. Someone would bring me soup, and I used to give breadcrumbs to the ants. I used to eat my bread with the liquid. Some people heard of this and asked me about it, and I told them: 'The ant and the bee nations are republicans; I give the ants the breadcrumbs out of respect for their republicanism.' They said: 'You are opposing the early leaders of Islam.' I replied: 'The Rightly-Guided Caliphs were both Caliph and presidents of the republic. Surely Abu Bakr the Veracious (May God be pleased with him), was surely a head of state for the Ten Promised with Paradise and the Companions of the Prophet. They were the heads of a religious republic that represented the truth of justice and freedom to the extent limited by the Shari'a, and not some meaningless name and frame. ${ }^{40}$

Nursi argues that "it is possible to deduce the truths of constitutionalism explicitly, implicitly, permissibly, from the Four Schools of Islamic Law." ${ }^{41}$ Nursi, therefore, establishes that there is no conflict between Islam and constitutionalism or democracy. As Çengel notes, Nursi in fact equates constitutionalism with Shari'ah in the sense that both are opposed to despotism and oppression. Nursi says "[d]espotism is tyranny and oppression. Constitutionalism is justice and shari'ah." ${ }^{42}$ Furthermore, "[the] real path of true shari' ah is the truth of 
constitutionalism that conforms to shari'ah." ${ }^{43}$ At a time when many Muslim scholars opposed constitutionalism on the grounds that it was incompatible with Shari'ah, Nursi "accepted constitutionalism with proof from shari'ah."44

This is by far a more enlightened view of politics and the state than any held by our present 'ulama'. That fact points to a crisis in religious leadership within Malaysia. The situation is all the more critical because the various groups in power, as well as others who wield influence, have been far from decisive and vocal in noting the problems and exerting force and pressure on the relevant authorities to bring about the needed changes.

\section{Policy Recommendations}

- There is a need to educate Malaysian society about core Islamic values in order to counter prevalent feudalistic values. These Islamic values include: (1) a rational and egalitarian conception of authority; (2) limits to arbitrary power; (3) recognition of positive individualism and respect for the human personality; (4) the rule of law; (5) a humanistic conception of leadership; (6) ethical integrity and honesty in public office; (7) frugality; (8) social justice; (9) effort rather than unfair privileges; (10) the ideal of excellence for life on earth; (11) rationalism and the philosophical spirit; (12) disapproval of irrational belief and superstition; and (13) dignity of labour.

- As opposed to an alliance between capital and the religious bureaucracy to establish an authoritarian state with the trappings of religio-fascism, there is a need in Malaysia for us to make democracy part of our culture. One way to do this is by way of theologising democracy. Theologisation of democracy would stress egalitarian as opposed to feudal values and appeal to social justice along the lines of need (class) rather than religion or ethnicity.

\section{Notes}

* Syed Farid Alatas, a Malaysian national, is Professor of Sociology at the National University of Singapore. He lectured at the University of Malaya in the Department of Southeast Asian Studies prior to joining NUS.

1. This section covering the pre-financial crisis period is derived from my Democracy and Authoritarianism: The Rise of the Post-Colonial State in Indonesia and Malaysia (Basingstoke: Macmillan, 1997). 
2. Raymond Aron, Democracy and Totalitarianism (London: Weidenfeld and Nicholson, 1968), 83.

3. On the first eight, see NSTP, Elections in Malaysia: Facts and Figures (Kuala Lumpur: NSTP Research and Informations Services, 1994); Ahmad Fawzi Mohd Basri, Pilihan Raya Umum 1995: Mandat Baru Menjelang 2000, Dewan Masyarakat May 1995.

4. James Jesudason, 'Statist Democracy and the Limits to Civil Society in Malaysia,' Journal of Commonwealth and Comparative Politics 33, no. 3 (1995): 335-56.

5. John Girling, 'Development and Democracy in Southeast Asia', The Pacific Review 1, no. 4 (1988): 332-40, 335.

6. The reasons for this are explained later in the chapter, when the impact of capitalism on the peasantry is discussed.

7. Chandran Jeshurun, 'Government Responses to Armed Insurgency in Malaysia, 1957-82,' in Governments and Rebellions in Southeast Asia, ed. Chandran Jeshurun (Singapore: Institute of Southeast Asian Studies, 1985), 134-6.

8. Ibid., 137.

9. Christopher Chase-Dunn, Global Formation: Structures of the World-Economy (New York: Basil Blackwell, 1989), 113.

10. Karl Marx, The German Ideology: Part One with Selections from Parts two and Three and Supplementary Texts (New York: International Publishers, 1970), 79-80.

11. James V. Jesudason, Ethnicity and the Economy: The State, Chinese Business, and Multinationals in Malaysia (Singapore: Oxford University Press, 1989), 36-8.

12. Jomo Kwame Sundaram, A Question of Class: Capital, the State, and Uneven Development in Malaya (New York: Monthly Review Press, 1988), 266-9.

13. Yoshihara Kunio, The Rise of Ersatz Capitalism in South-East Asia (Singapore: Oxford University Press, 1988), 72-4.

14. Ibid.

15. Jesudason, Ethnicity and the Economy, 5.

16. Edmund Terence Gomez, Political Business in East Asia (London: Routledge, 2001), 39, 289-90.

17. Jesudason, Ethnicity and the Economy, 157.

18. Heng Pek Koon, 'The Chinese Business Elite of Malaysia,' in Southeast Asian Capitalists, ed. Ruth T McVey (Ithaca: Cornell University, 1992), 289.

19. Chandra Muzaffar, Freedom in Fetters: An Analysis of the State of Democracy in Malaysia (Penang: Aliran, 1986), 322.

20. 'MCA Pulls Out of Cabinet,' The Straits Times, 14 May 1969.

21. Goh Cheng Teik, The May Thirteenth Incident and Democracy in Malaysia (Kuala Lumpur: Oxford University Press, 1971), 28-9.

22. Anthony Ng, 'Think Again Plea: MCA leaders to meet soon,' The Straits Times, 31 May 1969.

23. Tunku Abdul Rahman Putra Al-Haj, May 13: Before and After (Kuala Lumpur: Utusan Melayu Press, 1969), 140; Goh, May Thirteenth, 30; Utusan Melayu, 6 and 7 June 1969.

24. Utusan Zaman, 20 July 1969. 
25. Barrington Moore, Social Origins of Dictatorship and Democracy: Lord and Peasant in the Making of the Modern World (Boston, MA: Beacon Press, 1966), 418.

26. Karl Marx, The Eighteenth Brumaire of Louis Bonaparte (New York: International Publishers, 1963).

27. James Illingworth, 'The Eighteenth Brumaire of Louis Bonaparte', International Socialist Review. Available at: https://isreview.org/issue/74/eighteenthbrumaire-louis-bonaparte (Accessed on: 15 October 2017).

28. Marx, The Eighteenth Brumaire of Louis Bonaparte, 67. The "sword of Damocles" is an allusion to the imminent danger faced by those in positions of power. Damocles was a member of the court of the $4^{\text {th }}$ century BC tyrant, Dionysius II of Syracuse, Sicily.

29. First discussed by Syed Hussein Alatas, 'Feudalism in Malaysian Society: A Study in Historical Continuity,' Civilisations 18, no. 4 (1968): 579-92.

30. Shahruddin Maaruf, 'Some Theoretical Problems Concerning Tradition and Modernization among the Malays of Southeast Asia' (Seminar papers, Department of Malay Studies, National University of Singapore, 2002/2003), 2.

31. 'Prof. Alatas sees Feudalism in Non-essential Spending,' The Straits Times, 9 August 1968.

32. 'Students' Union Hits at Varsity Council,' The Straits Times, 8 October 1966.

33. 'Malaysia Subscribes to the Conception of Democracy,' Eastern Sun, 30 December 1966.

34. Shahruddin Maaruf, Some Theoretical Problems Concerning Tradition and Modernization among the Malays of Southeast Asia (London: Time Academic Express, 1992) 16.

35. Ibid., 17.

36. Ibid.

37. For a brief discussion on theologising democracy, see Azhar Ibrahim, 'Theologising Democracy', in Power to the People? (Con-)tested Civil Society in Search of Democracy, ed. Heidi Moksnes and Mia Melin (Uppsala: Centre for Sustainable Development, 2010) 128.

38. Sükran Vahide, Islam in Modern Turkey: An Intellectual Biography of Bediuzzaman Said Nursi (Albany, NY: SUNY Press, 2005), 33-5.

39. Ibid., 94-5.

40. Bediuzzaman Said Nursi, The Rays Collection (Istanbul: Sözler Publications, 2002), 304-5.

41. Sükran Vahide, The Author of the Risale-i Nur, Bediuzzaman Said Nursi (Istanbul: Sözler Publications, 1992), 73. Cited in Yunus Çengel, 'Nursi's Approach to Modern Values, and Justice in Governing'. Available at: http:// www.bediuzzamansaidnursi.org/en/icerik/nursi\%E2\%80\%99s-approachmodern-values-and-justice-governing. (Accessed on: 10 October 2017).

42. Ibid.

43. Ibid.

44. Ibid. 